\title{
Additional Report on Calanoid Copepods from the Izu Region -Part 6. Phaennidae-
}

$\operatorname{AUTHOR}(S)$ :

Tanaka, Otohiko; Omori, Makoto

\section{CITATION:}

Tanaka, Otohiko ...[et al]. Additional Report on Calanoid Copepods from the Izu Region Part 6. Phaennidae-. PUBLICATIONS OF THE SETO MARINE BIOLOGICAL LABORATORY 1992, 35(4-5): 253-271

ISSUE DATE:

1992-03-31

URL:

http://hdl.handle.net/2433/176203

RIGHT: 


\title{
Additional Report on Calanoid Copepods from the Izu Region Part 6. Phaennidae
}

\author{
Otohiko TANaka ${ }^{1)}$ \\ 1-29-18 Sangenchaya, Setagaya-ku, Tokyo 154 \\ and \\ MAKOTO OMORI \\ Department of Aquatic Biosciences, Tokyo University of Fisheries, \\ 4-5-7 Konan, Minato-ku, Tokyo 108 \\ With Text-figures $1-8$
}

There have been many inconsistencies in classification of the family Phaennidae up to Bradford's (1973) redefinition. She placed 6 genera in this family: Brachycalanus Farran, Cephalophanes Sars, Cornucalanus Wolfenden, Onchocalanus Sars, Phaenna Glaus and Xanthocalanus Giesbrecht. Lately, additional 2 genera, Talacalanus Wolfenden and Xantharus Andronov, have been placed by Campaner (1978) and Andronov (1981), respectively. But Park (1983) considers that the separation of the genus Talacalanus from Xanthocalanus is not justifiable. Also, Bradford et al. (1983) do not agree with the proposal of Andronov. We have followed Bradford (1973) and have not include these two genera in this paper. Definitions of the 6 genera are given by Bradford et al. (1983), but those of male are not complete.

From the adjacent seas of Japan, 5 genera and 21 species of Phaennidae, including 5 species of Amallophora, have so far been reported (Tanaka, 1960, 1965; Tanaka and Omori, 1967). The genus Amallophora is a junior synonym of Xanthocalanus (see Bradford, 1973). In the present paper, 2 species of Cephalophanes, 2 species of Cornucalanus, 4 species of Onchocalanus including a questionable specimen, 1 species of Phaenna and 4 species of Xanthocalanus are reported (Table 1). Cephalophanes tectus

Table 1. List of species.

$\begin{array}{ll}\text { 1. Cephalophanes refulgens Sars } & \text { 8. Onchocalanus trigonoceps Sars } \\ \text { 2. C. tecius (Esterly) } & 9 . \text { Phaenna spinifera Claus } \\ \text { 3. Cornucalanus chelifer (Thompson) } & 10 . \text { Xanthocalanus greeni Farran } \\ \text { 4. C. indicus Sewell } & 11 . X . \text { maximus Brodsky } \\ \text { 5. Onchocalanus affinis With } & 12 . X . \text { pinguis Farran } \\ \text { 6. O. cristatus Wolfenden } & 13 . X . \text { serratus (Tanaka) } \\ \text { 7. O. hirtipes Sars } & \end{array}$

1) Bereaved on August 2, 1990.

Publ. Seto Mar. Biol. Lab., 35(4/5), 253-271, 1992. (Article 7) 
female and Cornucalanus indicus female and male are redescribed. Two new records have been established for the north-western Pacific. Sampling dates and the position of the sampling stations are shown in Part 4 (Tanaka and Omori, 1971) of the present series.

\section{Cephalophanes Sars, 1907}

Cephalophanes refulgens Sars, 1907

(Fig. 1 a-c)

Cephalophanes refulgens Sars 1907, p. 15; Farran, 1908, p. 49, pl. 5, figs. 5-7; Sars, 1925, p. 154, pl. 43, figs. 1-17; Steuer, 1926, p. 182, figs. 1-4; Wilson, 1950, p. 188; Vervoort, 1965, p. 34.

Cephalophanes frigidus Wolfenden. -Tanaka, 1960, p. 124, fig. 100.

Occurrence: Sta. 108, 1 ; ; Sta. 121-2, 1 \%.

Remarks: Antennule of C. refulgens extends to caudal ramus, and fifth leg armed with 4 spines on third segment of which the inner marginal spine extents beyond the end of distal spine of the same segment (Sars, 1925). In the present specimens, the inner marginal spine on third segment of fifth leg is the longest, but hardly extents beyond the end of distal spine. Other parts agree with description by Sars (1907, 1925). Farran (1929) notes that difference between C. refulgens and C. frigidus Wolfenden is small and there is a good deal of doubt on the specific distinctness between them. It is ture. However, in the latter species the antennule extends only to the genital complex, and third segment of fifth leg lacks inner marginal spine (Wolfenden, 1911). If these differences are specific, the specimen recorded from Sagami Bay and identified as C. frigidus by Tanaka (1960) seems to be closer to C. refulgens than to C. frigidus.

Distribution and size variation:

\begin{tabular}{|c|c|c|c|c|}
\hline \multirow[t]{2}{*}{ Author } & \multirow[t]{2}{*}{ Locality } & \multirow[t]{2}{*}{ Depth (m) } & \multicolumn{2}{|c|}{ Body length (mm) } \\
\hline & & & 우 & $\partial$ \\
\hline Sars, 1907 & Azores, North Atlantic & $0-3250$ & 4.20 & - \\
\hline Farran, 1908 & Irish Atlantic slope & $1040-1220$ & - & - \\
\hline Steuer, 1926 & $\begin{array}{l}\text { Tropical and } \\
\text { subtropical Atlantic }\end{array}$ & $0-1500$ & $4.0-4.5$ & 3.2 \\
\hline Vervoort, 1965 & Off Liberia & $0-1750$ & $4.00-4.13$ & - \\
\hline Present record & Tzu region & $0-930$ & $4.16-4.90$ & - \\
\hline
\end{tabular}

Cephalophanes tectus (Esterly, 1911)

(Fig. $1 \mathrm{~d}-\mathrm{j}$ )

Xanthocalanus tectus Esterly, 1911, p. 324, pl. 28, fig. 33, p. 29, fig. 53, pl. 31, fig. 95; Brodsky, 1950, p. 232, fig. 144.

Cephalophanes tectus (Esterly). -Grice, 1969, p. 453, figs. 55-57.

Occurrence: Sta. 111-2, 1; Sta. 114, 1; Sta. 120, 2 우. 
Descriptive notes: Female, $4.10 \mathrm{~mm}$. Prosome/urosome length ratio 81:19. Prosome length/width ratio about 3:1. Cephalosome, with pair of large eyes, separated from first metasomal segment; fourth metasomal segment separated from the fifth. Lateral corners of last metasomal segment narrowly round with pointed apex. Rostral filaments slender.

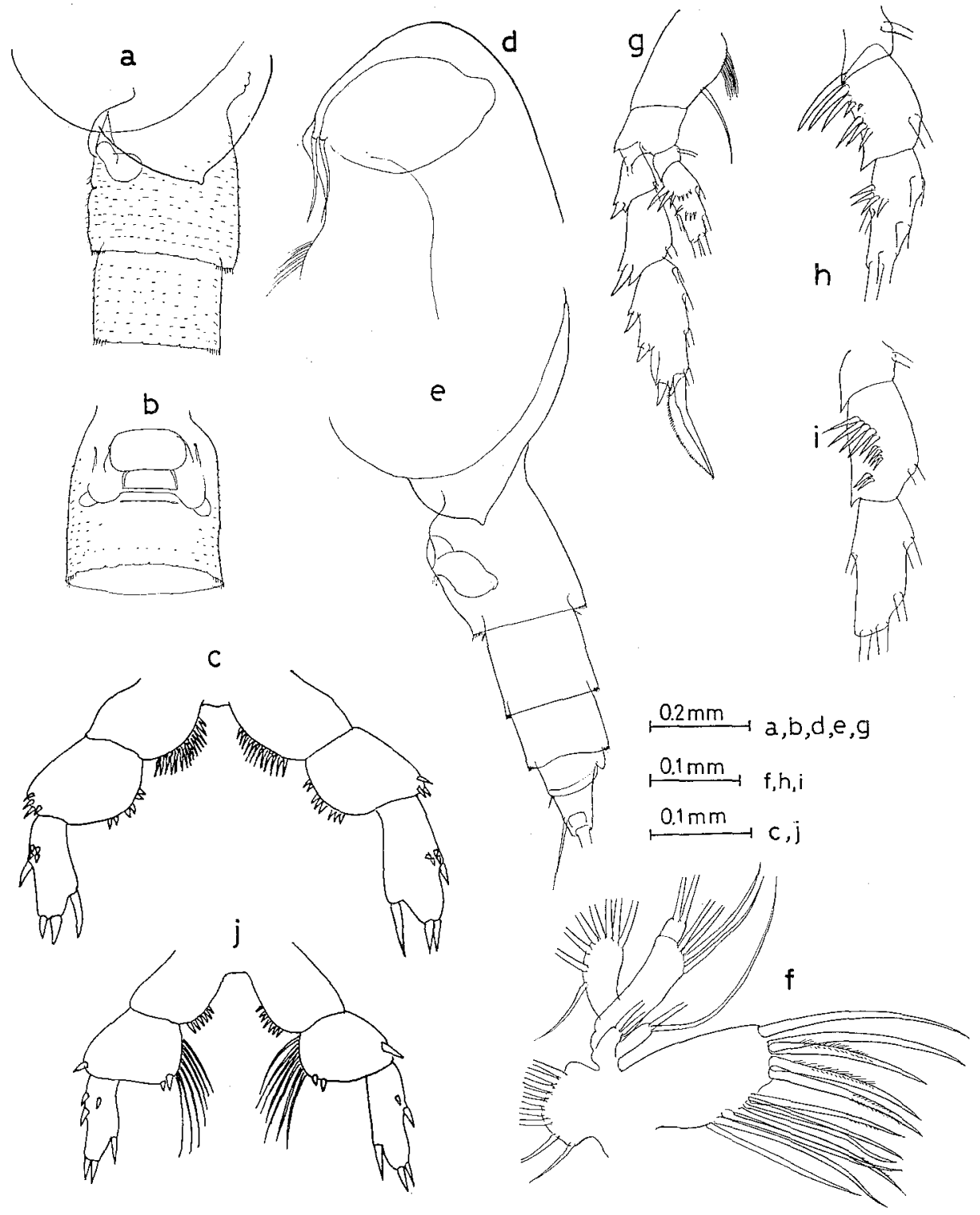

Fig. 1. Cephalohanes refulgens female. a, last metasomal segment and genital complex, lateral; b, genital complex, ventral; c, fifth leg. Cephalophanes tectus female, d, forehead, lateral; e, posterior part of body, lateral; f, maxillule; g, second leg; h, endopod of third leg; i, endopod of fourth leg; j, fifth leg. 
Urosomal segments and caudal ramus (c.r.) have proportional lengths:

segment $\frac{1-2}{42} \quad \frac{3}{21} \quad \frac{4}{16} \quad \frac{5}{4} \quad \frac{\text { c.r. }}{17}=100$.

Genital complex with length/width ratio $8: 7$. Caudal ramus with length/width ratio $2: 3$.

Antennule extending beyond end of caudal ramus with 4 segments; proportional lengths of various segments are as follows:

\begin{tabular}{|c|c|c|c|c|c|c|c|c|c|c|c|c|c|c|c|c|}
\hline \multirow[t]{2}{*}{ segment } & 1 & 2 & 3 & 4 & 5 & 6 & 7 & $8-9$ & 10 & 11 & 12 & 13 & 14 & 15 & 16 & 17 \\
\hline & 37 & $\overline{48}$ & 26 & 22 & 26 & 26 & 27 & 46 & 28 & 35 & $\overline{38}$ & 44 & 44 & 51 & 53 & 55 \\
\hline & 18 & 19 & 20 & 21 & 22 & 23 & 24 & 25 & & & & & & & & \\
\hline & 53 & 53 & 50 & 48 & 40 & 53 & 55 & $42=$ & 10 & & & & & & & \\
\hline
\end{tabular}

Exopod of antenna is a little longer than endopod (7:6); exopod 7-segmented; endopod armed with 6 setae outer lobe and 8 setae on inner lobe. Mandible with 2 marginal setae; basis of exopod armed with 6 setae; endopod armed with 9 setae on second segment. Maxillule with the following number of setae: 9 on outer lobe, 8 on exopod, 4 on basis, 2 on endopod, and 2 on third, 2 on second and 12 on first inner lobe. Fifth lobe with 2 large spiniform setae of which one is finely serrated on anterior margin; endopod with 7 brushform and 1 vermiform sensory filaments. First syncoxa and basis of maxilliped are about equal in length; syncoxa armed with 7 setae and 1 short bud-like sensory filament; basis with a row of fine spinules on the proximal margin, and bears 3 middle setae and 2 distal setae; endopod half the length of basis; distal setae of the endopod are short.

First leg with 3-segmented exopod and 1-segmented endopod. Second leg with 3-segmented exopod and 2-segmented endopod. Third and fourth legs with 3segmented exopod and endopod; second and third endopodal segments of third leg armed with groups of spines; third endopodal segment of fourth leg lacks spines. Fifth leg 3-segmented; first segment with 6-7 spinules, second segment with long bristles and 3 short spinules on the inner margin; third segment with 4 spines of which inner marginal spine hardly reaches to the end of distal spines.

Remarks: In his description of Xanthocalanus tectus, Esterly (1911) seems to overlooked a pair of large eyes in forehead which are marked character of Cephalophanes. Park (1983) suggested that $C$. tectus is synonymous with $C$. refulgens, but C. tectus is distinguishable from the latter species by having long bristles on the inner margin of second segment of fifth leg. This is new record of occurrence in the adjacent seas of Japan.

Distribution and size variation:

$\begin{array}{ll}\text { Author } & \text { Locality } \\ \text { Esterly, 1911 } & \text { San Diego region } \\ \text { Brodsky, 1950 } & \text { Far-eastern seas of } \\ & \text { the USSR } \\ \text { Grice, 1969 } & \text { Gulf of Mexico } \\ \text { Present record } & \text { Izu region }\end{array}$

\begin{tabular}{llr} 
Depth (m) & \multicolumn{2}{c}{ Body length (mm) } \\
& o & \% \\
$0-531$ & 4.25 & - \\
$550-650$ & 4.25 & - \\
& & - \\
$0-430$ & 4.00 & - \\
$0-930$ & $4.10-4.23$ & -
\end{tabular}




\title{
Cornucalanus Wolfenden, 1905
}

\author{
Cornucalanus chelifer (Thompson, 1903)
}

(Fig. 2 a-c)

Scolecithrix chelifer Thompson, 1903, p. 21, pl. 5, figs. 1-9; Farran, 1905, p. 36, pl. 7, figs. 18, 19.

Cornucalanus chelifer (Thompson). -Farran, 1908, p. 49; With, 1915, p. 222, pl. 7, fig. 4, pl. 8, fig. 5; Sars, 1925, p. 151, pl. 42, figs. 1-14; Sewell, 1929, p. 177, fig. 64; Vervoort, 1957, p. 91; Tanaka, 1960, p. 121, fig. 98; Bradford et al., 1983, p. 61; Park, 1983, p. 352, figs. 23-26.

Cornucalanus magnus Wolfenden. -Wolfenden, 1911, p. 281, pl. 32, figs. 1-10, textfig. 45.

Occurrence: Sta. 108, 1 우 Sta. 109, 1우 Sta. 121-2, 2 우.

Remarks: Cornucalanus chelifer is easily recognized by a well-marked cephalic spine on the forehead and a single terminal spine and patches of hairs of fifth leg. The species is widely distributed in deep waters of the Atlantic and Indo-Pacific Oceans, but this is the first record of adult females in the adjacent waters of Japan.

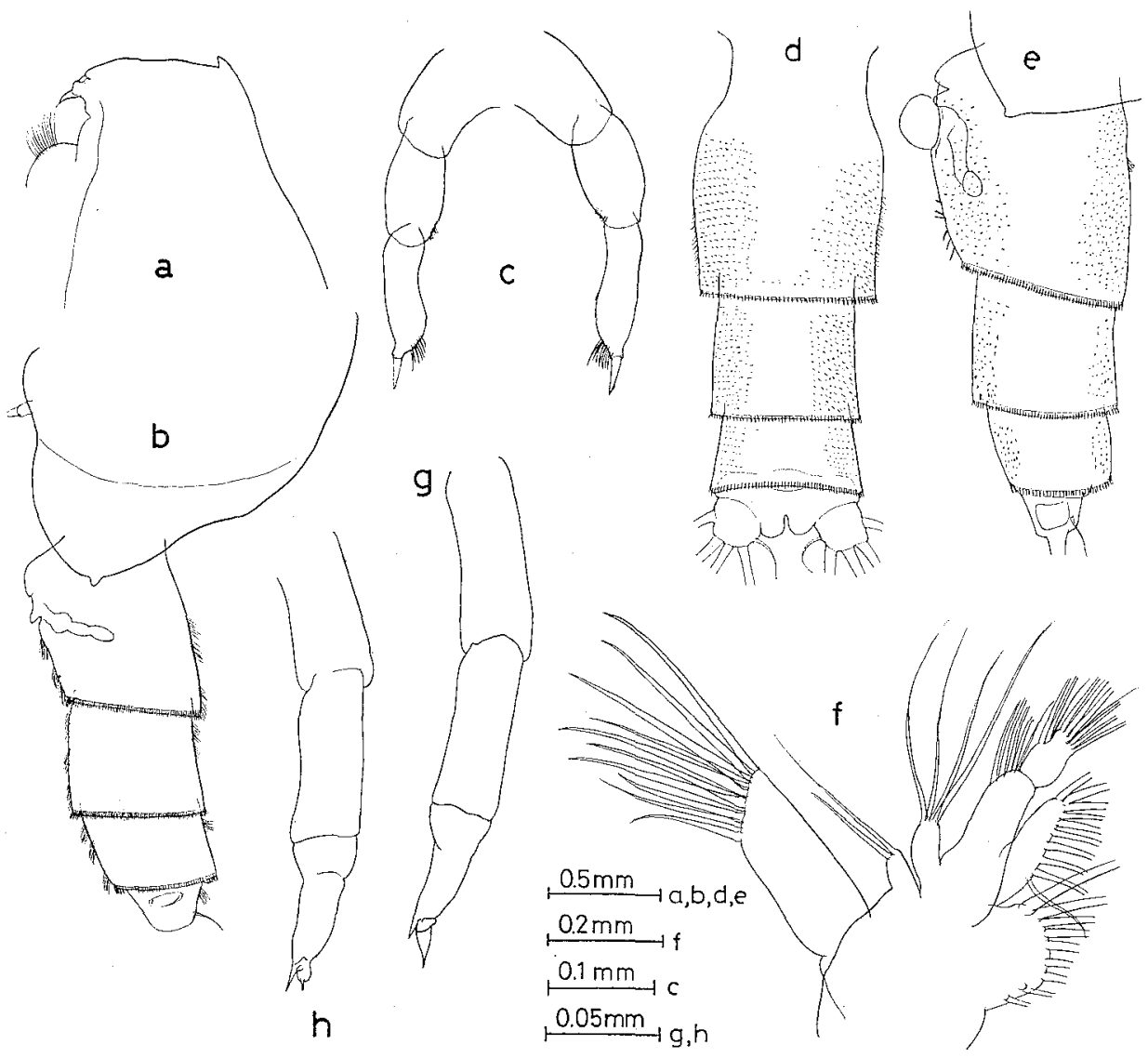

Fig. 2. Cornucalanus chelifer female. a, forehead, lateral; b, posterior part of body, lateral; c, fifth leg. Cornucalanus indicus female. d, urosome and caudal rami; e, the same, lateral; $f$, maxillule; $g$ and $h$, fifth leg. 
Distribution and size variation:

\begin{tabular}{lllcc} 
Author & Locality & Depth $(\mathrm{m})$ & \multicolumn{2}{c}{ Body length $(\mathrm{mm})$} \\
& & $0-1960$ & 6.0 & ơ \\
Thompson, 1903 & Irish Atlantic slope & $0-3000$ & $7.8-8.0$ & - \\
Wolfenden, 1911 & $\begin{array}{l}\text { Tropical and subtropical } \\
\text { Atlantic }\end{array}$ & $0-1800$ & 8.7 & 6.17 \\
With, 1915 & Denmark Strait & $0-1500$ & 8.4 & - \\
Sars, 1925 & North Atlantic & $0-914$ & 7.6 & 6.3 \\
$\begin{array}{l}\text { Bradford et al., } \\
\quad \text { Off New Zealand }\end{array}$ & & & \\
Park, 1983 & Antarctic waters & $0-625$ & $7.41-8.25$ & $6.35-6.66$ \\
Present record & Izu region & $0-1000$ & $7.2-7.6$ & -
\end{tabular}

Cornucalanus indicus Sewell, 1929

(Figs. 2 d-h, 3 a-o)

Cornucalanus indicus Sewell, 1929, p. 179, fig. 66; Brodsky, 1950, p. 236, fig. 148; Vervoort, 1957, p. 93; Tanaka, 1960, p. 122, fig. 99; Tanaka and Omori, 1967, p. 250; Brodsky and Zvereva, 1976, p. 188, figs. 27-31.

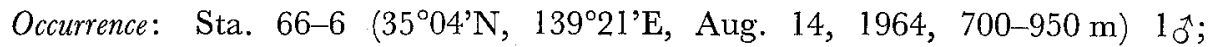

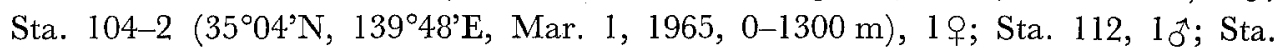
$185\left(34^{\circ} 43^{\prime} \mathrm{N}, 139^{\circ} 38^{\prime} \mathrm{E}\right.$, July $\left.24,1966,0-2000 \mathrm{~m}\right), 1$ ㅇ.

Descriptive notes: Female, $9.0 \mathrm{~mm}$, from Sta. 104-2. Prosome/urosome length ratio 74:26. Forehead round with no trace of cephalic spine. Urosome covered with spinules; various segments and caudal ramus have proportional lengths:

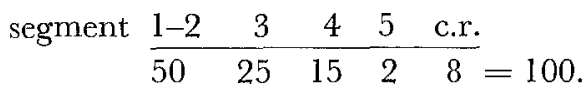

Lateral margin of genital complex inflated; genital tubercle prominent.

Antennules are broken off in the distal segments. Mandible with 3 setae on basis; exopod armed with 6 setae; endopod with 2 and 9 setae on first and second segment, respectively. Maxillule with the following number of setae: 9 on outer lobe, 10 on exopod, 5 on basis, 10 on endopod, and 4 on third, 2 on second and 10 on first inner lobe. Other appendages agree well with the description and figures by Sewell (1929).

First leg has 3-segmented exopod; first segment lacks spinule; second segment with a group of 8 spinules at the base of inner marginal spine; third segment with 3 groups of 5,9 and 6 spinules on the right and 6,5 and 15 spinules on the left leg; endopod 1-segmented, and bearing 8 spinules. Fifth leg very small, 3 -segmented; second segment longer than the third segment; there is a faint line of demarcation near the proximal one-third of third segment; third segment armed with a large inner terminal spine and small outer spine, although the inner terminal spine not developed well in another specimen.

Male, $8.28 \mathrm{~mm}$, from Sta. 66-6. Prosome/urosome lengths ratio 77:23. Pro- 
some elongate ovate, 2.5 times as long as wide. Cephalosome separated from first metasomal segment; fourth and fifth metasomal segments incompletely separated by a line of demarcation. Laterodistal margins of last metasomal segment produc-
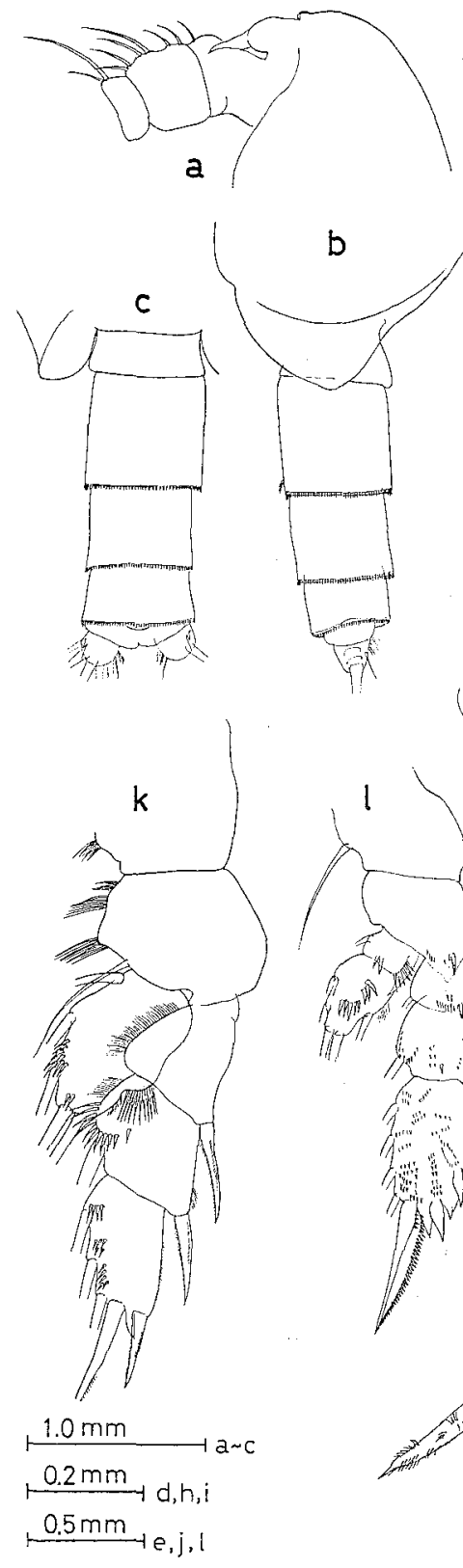

$b$
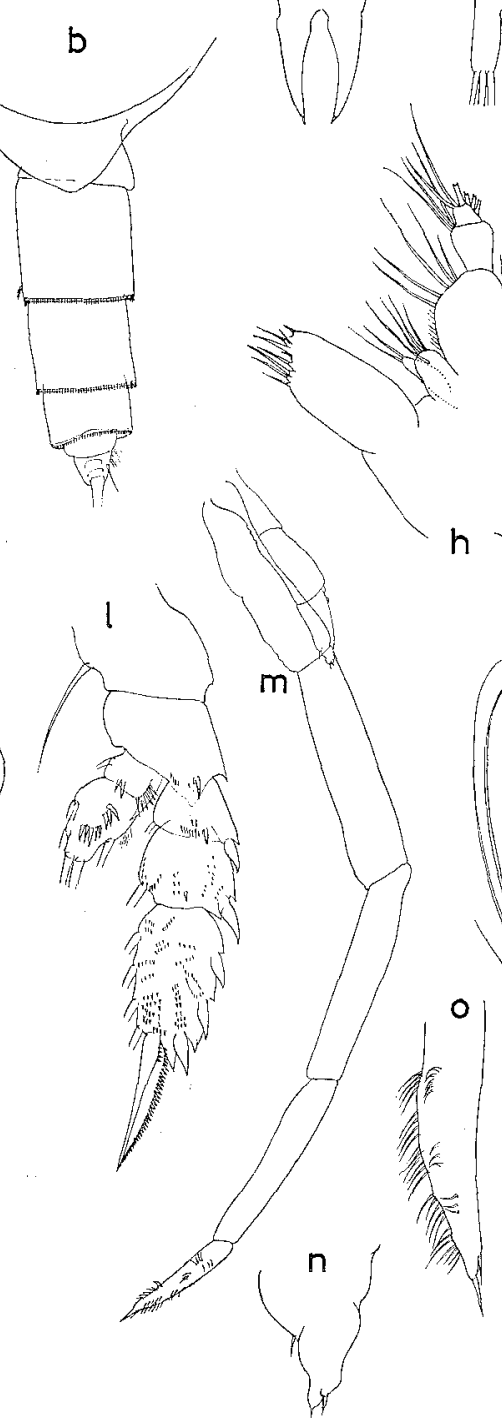

Fig. 3. Cormucalanus indicus male. a, forehead, lateral; b, posterior part of body, lateral; $c$, the same, dorsal; $d$, rostrum; e, antenna; $f$, mandibular palp; $g$, cutting edge of mandibular blade; h, maxillule; $i$, maxilla; $j$, maxilliped; $k$, first leg, posterior; 1 , second leg; $m$, fifth leg; $n$, distal part of the same, right; o, the same, left. 
ed backward into triangular expansion with narrowly rounded apex. Rostrum consist of a plate with stout rami, each of which is followed by a small projection at apex.

Urosomal segments, without spinules, and caudal ramus have following proportional lengths:

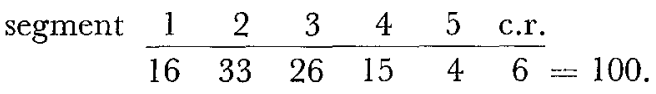

Antennule extends to end of first urosomal segment; proportional lengths of various segments are as follows:

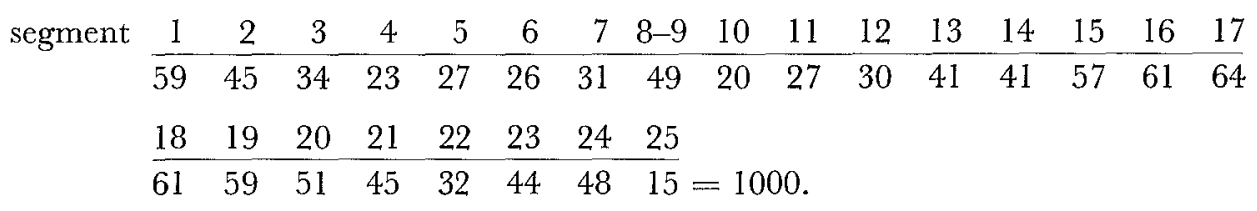

Antenna biramous; exopod and endopod are about the same length: second exopodal segment armed with 2 setae, third to fifth segments each with a single seta; endopod with 6 setae on outer lobe and 8 setae on inner lobe. Mandible robust with 2 setae on basis; 6 setae on exopod; endopod with 1 seta on first and 8 setae on second segment. Maxillule reduced, and bearing the following number of setae: 7 on outer lobe, 9 on exopod, 5 on basis, $3+6$ on endopod, and 4 on third and 2 on second inner lobe; first inner lobe large but only armed with few small setae. Maxilla reduced; fourth and fifth lobes each armed with a large claw-like spiniform seta; endopod with 8 weak sensory filaments of which one is slender and longer than others. Syncoxa and basis of maxilliped are about equal in length; syncoxa armed with a small worm-like sensory appendage on the middle; endopod half the length of basis; 2 setae on distal 2 segments are longer than others.

Exopod of first leg 3-segmented; second segment armed with a group of 11 spinules at the base of inner marginal spine; third segment with 3 groups of 4, 5 and 5 spinules; endopod 1 -segmented with $8+2$ spinules. Second leg with 3 -segmented exopod and 2-segmented endopod; both rami armed with groups of spinules on posterior surface, but the spinules on endopod are larger than those on exopod. Both rami of third and fourth legs 3 -segemented with groups of spinules on the posterior surfaces. Fifth legs, the right leg 3-segmented; the distal segment armed with 2 spines; left leg 5-segmented and long; first to fourth segments are about equal in length; fifth segment short, and with 1 distal and il lateral spine and patches of hairs.

Remarks: Males of Cornucalanus and Onchocalanus resemble each other. However, in Cornucalanus, fourth and fifth lobes of maxilla armed with large spiniform setae, whereas in Onchocalanus only fifth lobe armed with spiniform seta.

The following 7 species of Cornucalanus have so far been described: C. antarcticus Brodsky and Zvereva, 1976; C. chelifer, C. indicus, C. notabilis Brodsky and Zvereva, 
1976; C. robustus Vervoort, 1957, C. sewelli Vervoort, 1957 and C. simplex Wolfenden, 1905. Cornucalanus antarcticus is considered to be a junior synonym of C. robustus (Park, 1983). Males of $C$. chelifer, $G$. indicus and C. robustus are known, but their diagnostic characters which are based on a few specimens are insufficient, making separation from each other uneasy. Park (1983) suggests that lateral view of forehead and rostrum, shape of spiniform setae of maxilla, and proportional lengths of fourth and fifth segments of left fifth leg are useful characteristics to separate $C$. robustus from C. chelifer. Male of $C$. indicus described by Brodsky and Zvereva (1976) has a forehead shape similar to that of $C$. chelifer, but the present male specimen is more similar to $C$. robustus than $C$. chelifer in the same aspect. Cornucalanus indicus is largest species in the genus, with males of all other species being smaller than $7.00 \mathrm{~mm}$.

Distribution and size variation:

\begin{tabular}{lllcc} 
Author & Locality & Depth $(\mathrm{m})$ & \multicolumn{2}{c}{ Body length $(\mathrm{mm})$} \\
& & & + & 0 \\
Sewell, 1929 & Bengal Bay & $0-730$ & 8.0 & - \\
Brodsky, 1950 & Northeastern Pacific & $1000-4000$ & $8.8-9.24$ & - \\
$\begin{array}{c}\text { Tanaka and } \\
\quad \text { Omori, 1967 }\end{array}$ & Izu region & $0-1300$ & $8.2-9.0$ & - \\
$\begin{array}{c}\text { Brodsky and } \\
\quad \text { Zvereva, 1976 }\end{array}$ & Bering Sea & - & - & $7.30-7.65$ \\
$\begin{array}{l}\text { Present record } \\
\text { Izu region }\end{array}$ & & $0-1300$ & $8.9-9.0$ & 8.28
\end{tabular}

\section{Onchocalanus Sars, 1905}

Onchocalanus affinis With, 1915

(Fig. 4 a-e)

Onchocalanus affinis With, 1915, p. 233, textfigs. 76, 77; Sars, 1925, p. 150, pl. 41, figs. 12-18; Sewell, 1947 , p. 135, figs. 32, 33; Vervoort, 1950a, p. 26, figs. 12-14; Wilson, 1950, p. 273, p. 26, fig. 381 ; Tanaka, 1960, p. 119, fig. 97.

Onchocalanus hirtipes, A. Scott, 1909, p. 83, pl. 34, figs. 9-17 (non Sars).

Occurrence: Sta. 93-2, 3q; Sta. 108, 2 q; Sta. 109, 1q; Sta. 115-1, 1 ㅇ․

Remarks: The female specimen, $6.0 \mathrm{~mm}$, agreed well with the description by Sewell (1947), except for maxillule of which first inner lobe bearing 10 setae, second and third lobes with 2 and 4 setae, respectively. First exopodal segment of first leg armed with 3-4 spinlues at base of outer marginal spine; second segment with 11 spinules and third segment with 3 groups of 3,9 and 7 spinules, respectively. Distal segment of fifth leg armed with 2 apical spines and 1 outer marginal spine.

Distribution and size variation:

\begin{tabular}{llllc} 
Author & Locality & Depth $(\mathrm{m})$ & \multicolumn{2}{c}{ Body length } \\
& & & \multicolumn{1}{c}{ (mm) } \\
Scott, A. 1909 & Malucca Sea & $0-1536$ & 5.0 & - \\
With, 1915 & Off lceland & $0-1800$ & 6.30 & 5.19 \\
Sars, 1925 & North Atlantic & $0-3000$ & 5.5 & - \\
Sewell, 1947 & Arabian Sea & $0-850$ & 5.13 & - \\
Vervoort, 1950a & Flores Sea & $0-2500$ & 4.85 & 4.10 \\
Tanaka, 1960 & Izu region & $0-1000$ & - & 5.86 \\
Vervoort, 1965 & Gulf of Guinea & $0-1750$ & $4.8-4.9$ & $4.35-4.40$ \\
Present record & Izu region & $0-1300$ & $5.7-6.5$ & -
\end{tabular}




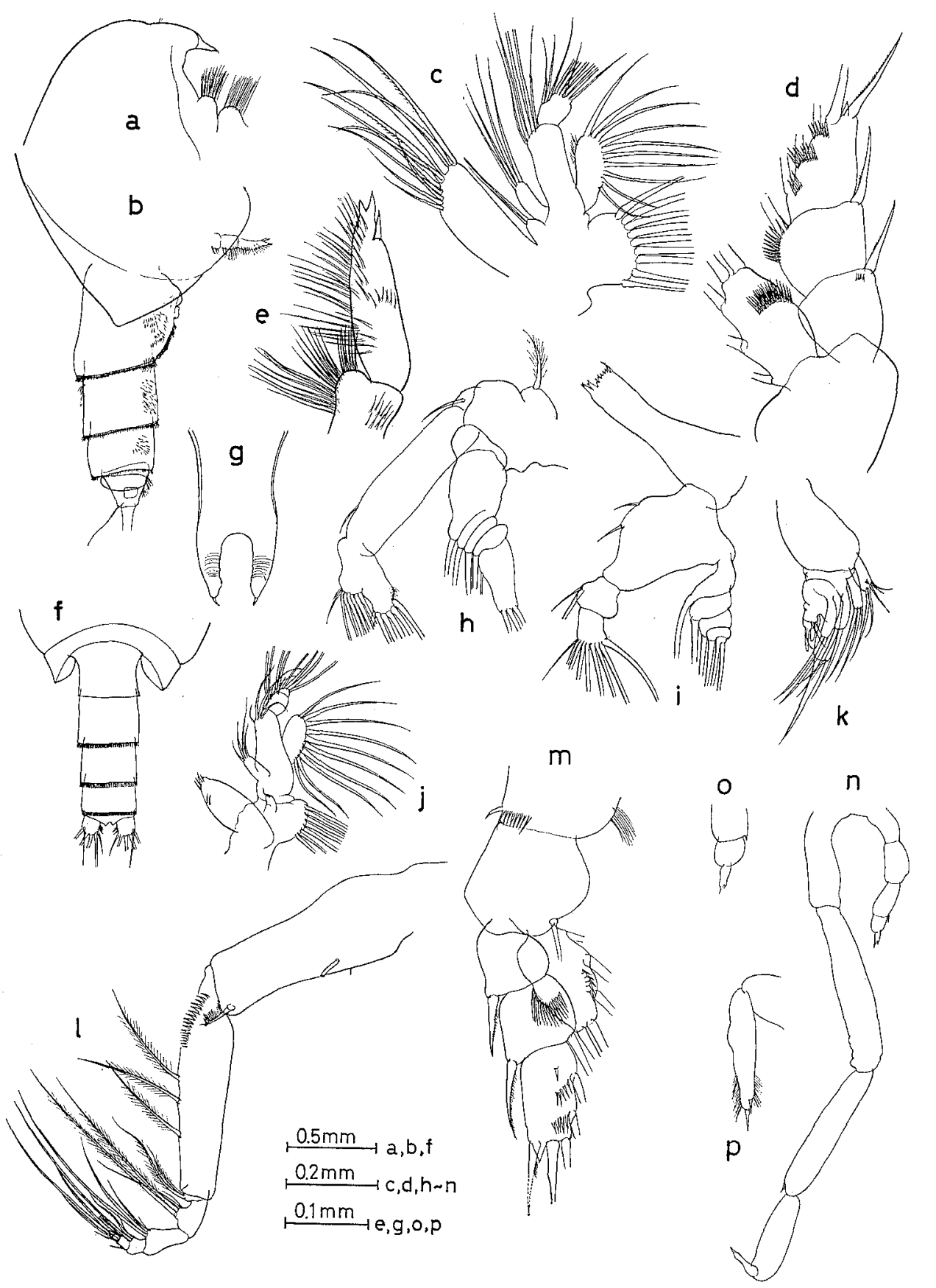

Fig. 4. Onchocalanus affinis female. a, forehead, lateral; $b$, posterior part of body, lateral; c, maxillule; d, first leg; e, distal segment of fifth leg. O. affinis? male. f, posterior part of body, dorsal; $g$, rostrum; $h$, antenna; $i$, mandible; $j$, maxillule; $k$, maxilla; 1, maxilliped; $m$, first leg; $n$, fifth leg; o, distal part of the same, right; $p$, the same, left. 


\section{Onchocalanus affinis?}

(Fig. 4 f-p)

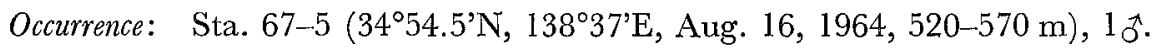

Descriptive notes: Male, $6.45 \mathrm{~mm}$. Prosome/urosome lengths ratio 77:23. Laterodistal margins of last metasomal segment narrowly rounded. Rostrum bearing a pair of spines with small filaments at apex.

Urosomal segments and caudal ramus have proportional lengths:

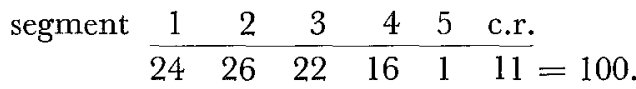

On antenna, endopod is 1.3 times the length of exopod; exopod with 5 setae on outer and 8 setae on inner lobe. Mandible as figured. Maxillule armed with the following number of setae: 7 on outer lobe, 10 on exopod, 5 on basis, $4+6$ on endopod, 4 on third and 1 on second inner lobe; setae on first inner lobe reduced. Maxilla reduced; first to fourth lobes with 5, 3, 3 and 3 setae, respectively; fifth lobe armed with 1 large spiniform and 3 small setae; endopod bearing 8 sensory filaments. First basal segment of maxilliped with small sensory appendage on the middle.

First leg, first and second exopodal segments lack spinules on posterior surface; third semgent with 3 groups of 1,5 and 5 spinules; endopod with 5 spinules. Fifth legs are 5-segmented on right and 4-segmented on left; distal segment of right leg armed with 2 small spines at distal margin; left leg long with apical spine and small subapical spine on distal segment, but lacks 3 short hairs on second segment of left fifth leg.

Remarks: Male of $O$. affinis closely resembles $O$. hirtipes Sars, and due to the limited number of specimens it is hard to distinguish them by direct comparison. Structure of fifth leg is not consistent between the two species. The present specimen is much larger than those reported by previous authors; it lacks spinules, on second exopodal segment of first leg, although Tanaka's (1960) specimen bears spinules on posterior surface. Therefore, we could not reach a conclusion that the species is definitely o. affinis.

\section{Onchocalanus cristatus (Wolfenden, 1904)}

$$
\text { (Fig. } 5 \text { a-j, } 6 \text { a-h) }
$$

Xanthocalanus cristatus Wolfenden, 1904, p. 119, pl. 9, figs. 18, 19.

Onchocalanus cristatus (Wolfenden). -A. Scott, 1909, p. 82, pl. 34, figs. 1-8; Wolfenden, 1911, p. 277; With, 1915, p. 228, pl. 7, fig. 6, pl. 8, fig. 17; Sars, 1925, p. 147, pl. 41, figs. 1-5; Vervoort, 1950a, p. 9, figs. 1, 2; Tanaka, 1960, p. 117, fig. 96; Vervoort, 1965, p. 31; Owre and Foyo, 1967, p. 57, figs. 100, 109, 111, 361-364; Bradford et al., 1983, p. 67, fig. 37; Park, 1983, p. 335, figs. 13-15.

Occurrence: Sta. 114, 1 ; Sta. 112, 10.

Remarks: Scott (1909) and Vervoort (1950) figure the distal segment of fifth leg bearing both inner and outer marginal spines, but the present specimen has the 


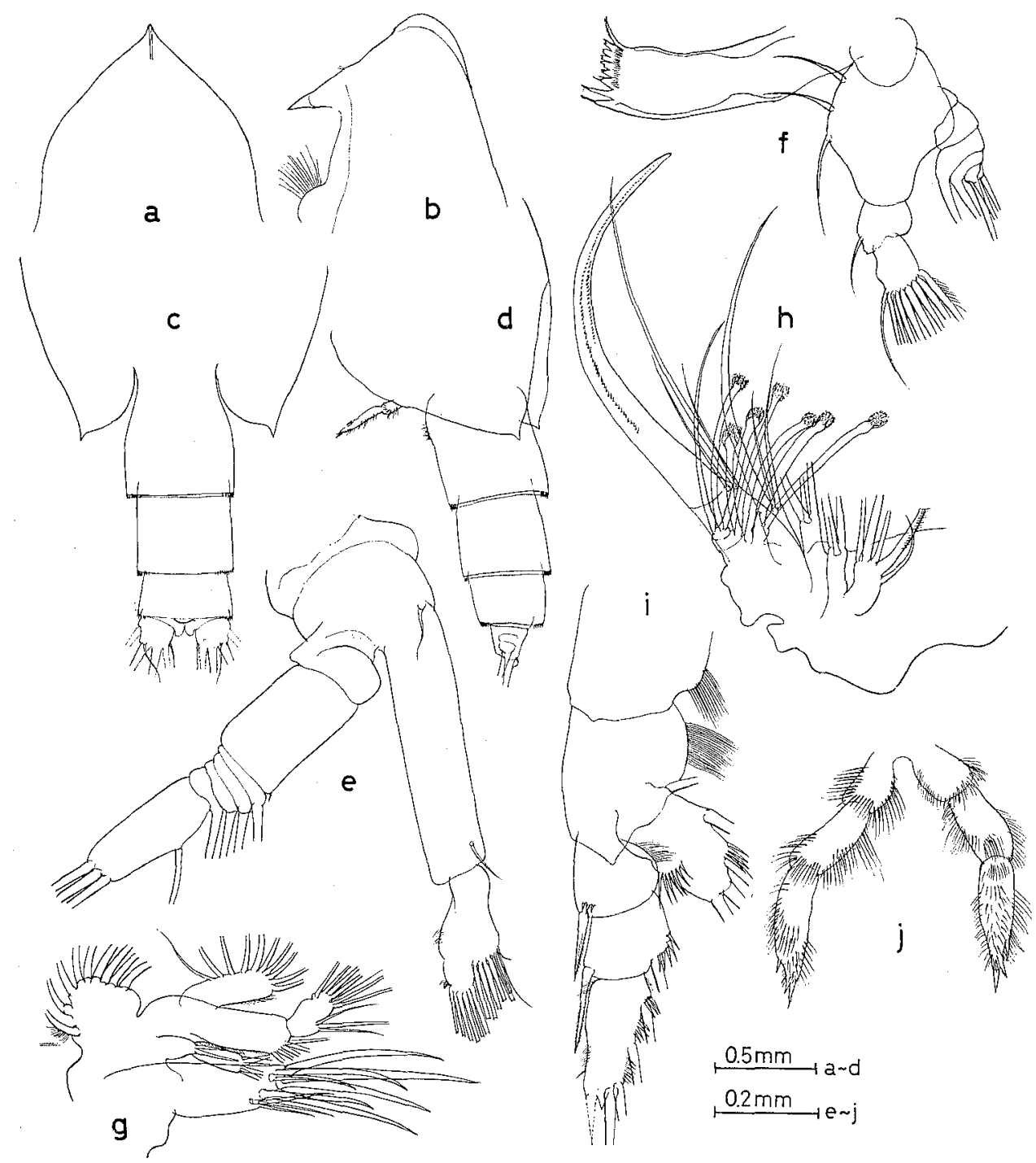

Fig. 5. Onchosalanus cristatus female. a, forehead, dorsal; b, the same, lateral; c, posterior part of body, dorsal; d, the same, lateral; e, antenna; f, mandible; $g$, maxillule; $h$, maxilla; $i$, first leg; j, fifth leg.

outer spine only. Body length of adult females considerably vary from 5.0 to 8.15 $\mathrm{mm}$, but so far none of morphological difference has been reported. The present male agrees well with the description of Tanaka (1960). Some appendages of both female and male from the present collections are illustrated in Figs. 5 and 6.

Distribution and size variation:

Author

Wolfenden, 1904

A. Scott, 1909

$$
\text { Locality }
$$

Off Ireland

Malay Archipelago

\begin{tabular}{ccc} 
Depth $(\mathrm{m})$ & \multicolumn{2}{c}{ Body length $(\mathrm{mm})$} \\
& 웅 & $\sigma^{7}$ \\
- & 5.0 & - \\
$0-1000$ & 6.6 & -
\end{tabular}


With, 1915

Sars, 1925

Tanaka, 1960

Vervoort, 1965

Vervoort, 1965

Owre and Foyo, 1967

Bradford et al., 1983

Park, 1983

Present record
Off Iceland

North Atlantic

Izu region

Malay Archipelago

Gulf of Guinea

Caribbean Sea

Off New Zealand

Antarctic waters

Izu region

$0-1800$
$0-3000$
$0-1000$
$0-3000$
$0-600$
$0-500$

500-1000

$0-625$

$0-900$
7.5-8.15

7.30

$-$

6.75

6.35

-

6.65

$7.16-7.75$

6.3
-

6.2

5.80-6.05

5.6

6.50

5.8

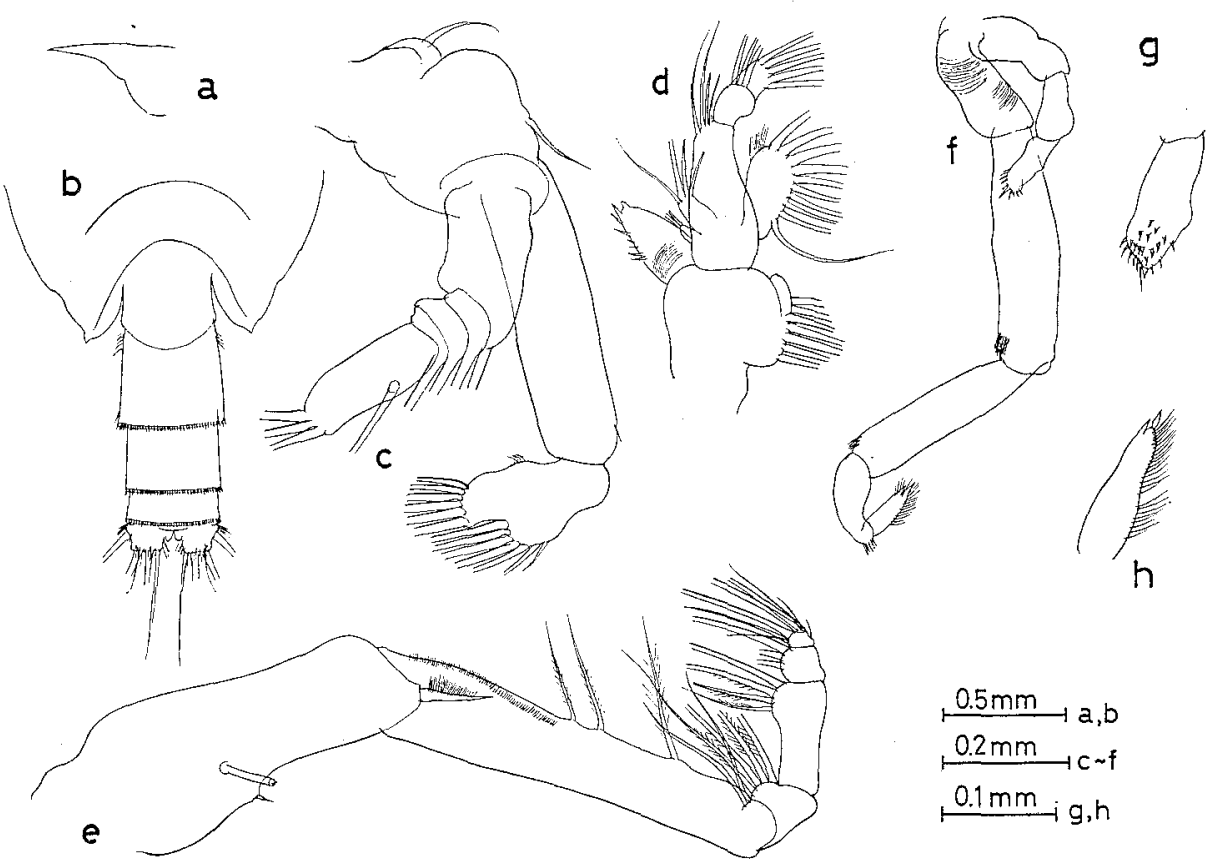

Fig. 6. Onchocalanus cristatus male. a, rostrum, lateral; b, posterior part of body, dorsal; c, antenna; d, maxillule; e, maxilliped; f, fifth leg; g, distal part of the same, right; $h$, the same, left.

Onchocalanus hirtipes Sars, 1905

(Fig. 7 a-j)

Onchocalanus hirtipes Sars, 1905, p. 20; With 1915, p. 231, textfig. 74; Sars, 1925, p. 148, pl. 41, figs. 6-11; Park, 1983, p. 351, fig. 22.

Occurrence: Sta. 108, 1 ㅇ․

Remarks: The present female specimen agreed well with description of With (1915). Park (1983) states that in his materials rostral rami have an obtuse distal end. However, in the present specimen rostrum has a pair of strong spines with a small filament at each apex. This is new record of occurrence in the adjacent seas 


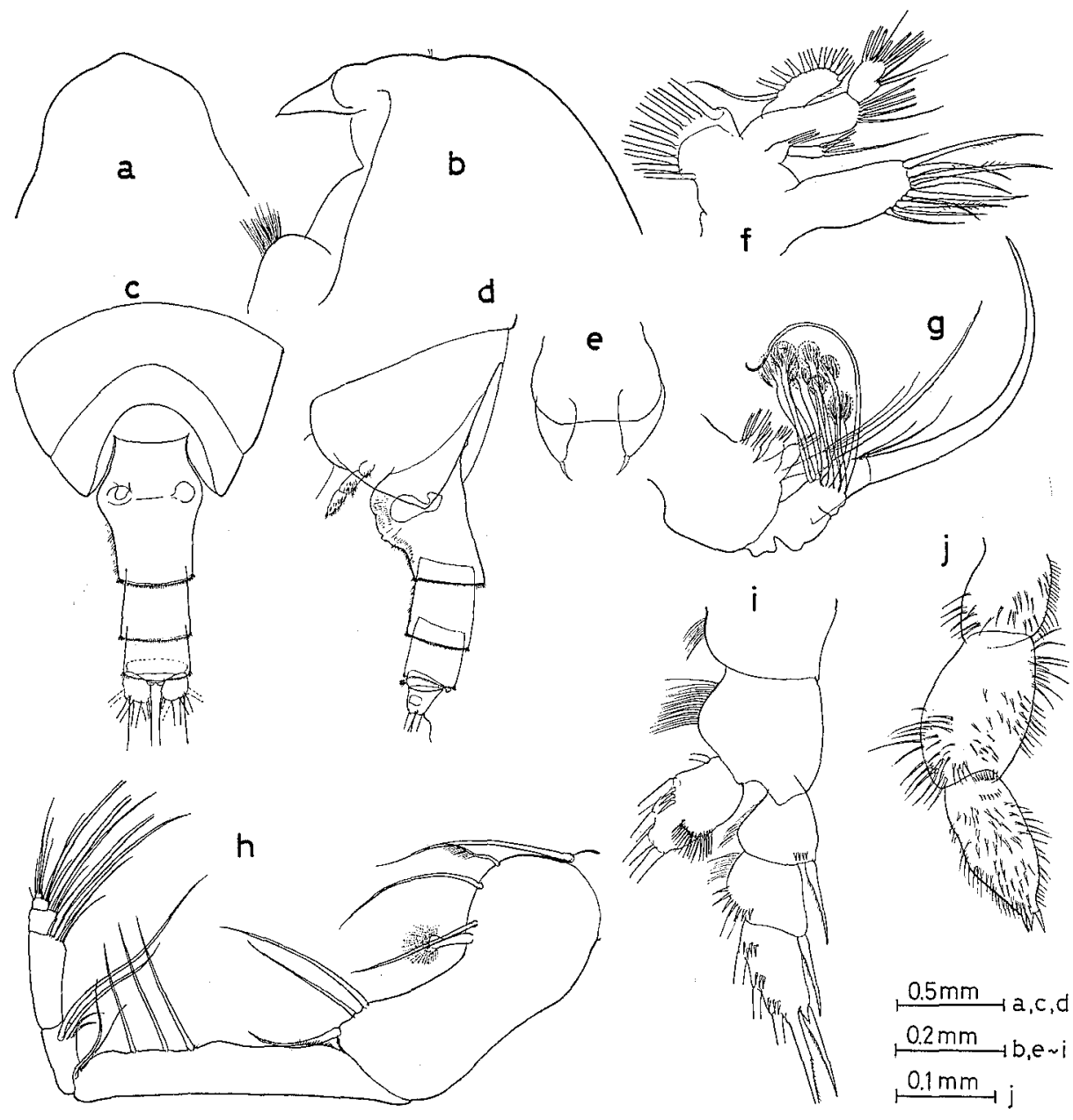

Fig. 7. Onchocalanus hirtipes female. a, forehead, dorsal; b, the same, lateral; $c$, posterior part of body, dorsal; d, the same, lateral; e, rostrum, anterior; f, maxillule; g, maxilla; $h$, maxilliped; i, first leg; $j$, fifth leg, right.

of Japan.

Distribution and size variation:

\begin{tabular}{|c|c|c|c|c|}
\hline \multirow[t]{2}{*}{ Author } & \multirow[t]{2}{*}{ Locality } & \multirow[t]{2}{*}{$\operatorname{Depth}(\mathrm{m})$} & \multicolumn{2}{|c|}{ Body length (mm) } \\
\hline & & & $q$ & $0^{*}$ \\
\hline Farran, 1908 & Off Ireland & $0-2104$ & 5.7 & - \\
\hline With, 1915 & Off Iceland & $0-1800$ & 5.3 & 4.04 \\
\hline Sars, 1925 & North Atlantic & $0-3000$ & 4.8 & - \\
\hline Park, 1983 & Antarctic waters & $0-1000$ & $5.16-5.33$ & _ \\
\hline Present record & Izu region & $0-1000$ & 5.05 & - \\
\hline
\end{tabular}


Onchocalanus trigonoceps Sars, 1905

(Fig. 8 a-f)

Onchocalanus trigonoceps Sars, 1905, p. 20; 1925, p. 144, pl. 40, figs. 1-15; Sewell, 1947, p. 139, fig. 34; Vervoort, 1950a, p. 12, figs. 3, 4; Tanaka, 1960, p. 115, fig. 95; Bradford et al., 1983, p. 67, figs. 38, 89; Park, 1983, p. 329, figs. 7-9.

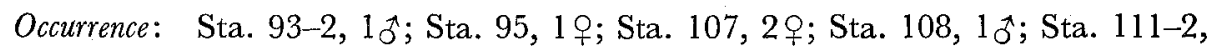
4우 Sta. 115-2, 2우 Sta. 117-2, 1 ㅇ․

Remarks: The present female and male specimens agreed with the descriptions and figures of Vervoort (1950a) and Park (1983).

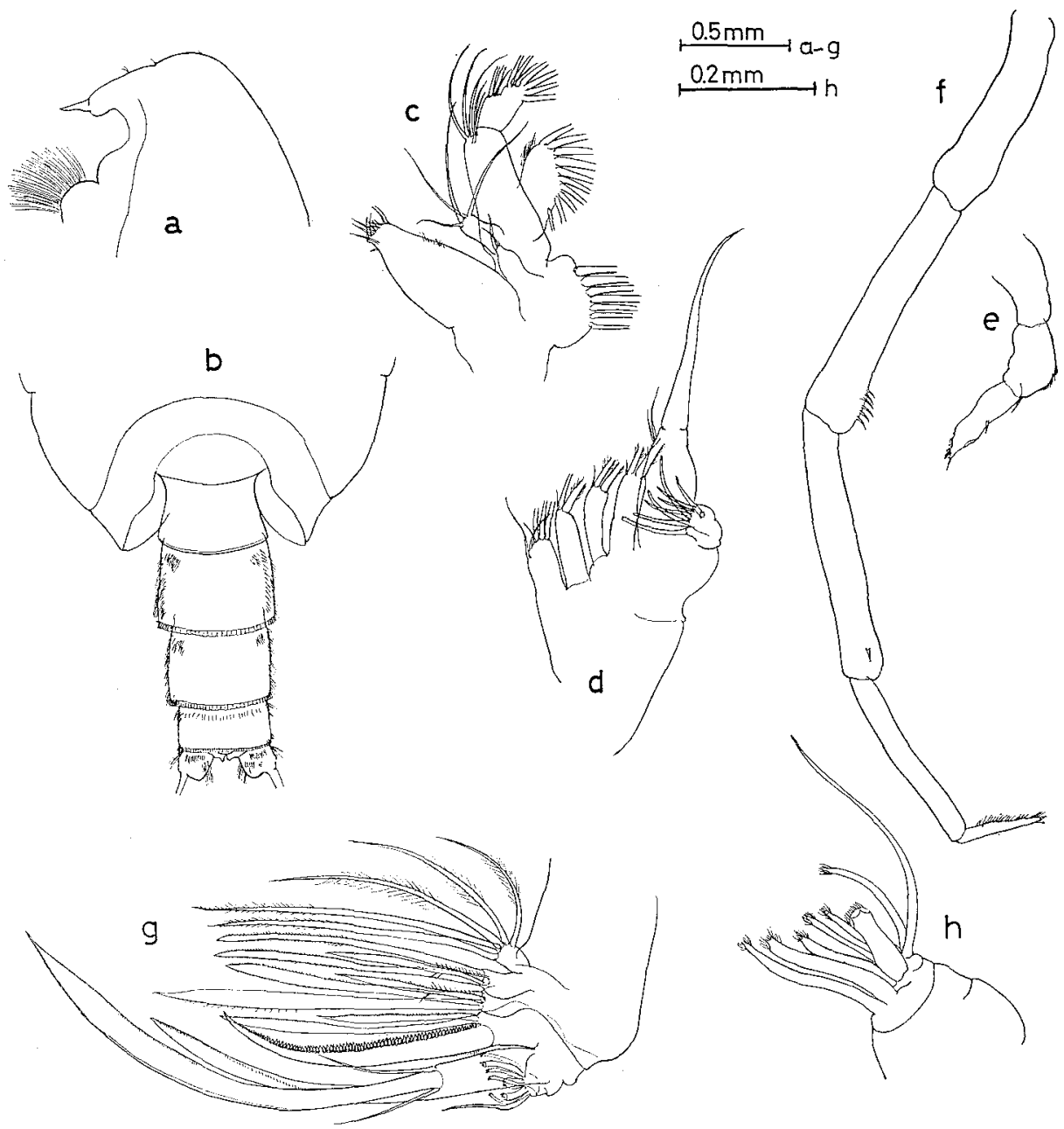

Fig. 8. Onchocalanus trigonoceps male. a, forehead, lateral; b, posterior part of body, dorsal; $c$, maxillule; d, maxilla; e, fifth leg, right; $f$, the same, left. Xanthocalanus maximus female. $g$, maxilla; $h$, sensory filaments of the same. 
Distribution and size variation:

\begin{tabular}{|c|c|c|c|c|}
\hline \multirow[t]{2}{*}{ Author } & \multirow[t]{2}{*}{ Locality } & \multirow[t]{2}{*}{ Depth $(\mathrm{m})$} & \multicolumn{2}{|c|}{ Body length (mm) } \\
\hline & & & $q$ & $\tilde{\sigma}$ \\
\hline Sars, 1925 & North Atlantic & $0-3000$ & 7.50 & - \\
\hline Sewell, 1947 & Arabian Sea & $0-850$ & 7.33 & - \\
\hline Vervoort, 1965 & Malay Archipelago & $0-4000$ & $7.30-7.55$ & 4.85 \\
\hline Vervoort, 1965 & Gulf of Guinea & $0-600$ & 6.91 & $5.42-5.63$ \\
\hline $\begin{array}{l}\text { Tanaka and } \\
\text { Omori, } 1967\end{array}$ & Izu region & $0-1430$ & $8.2-8.9$ & - \\
\hline $\begin{array}{l}\text { Bradford et al., } \\
\quad 1983\end{array}$ & Off New Zealand & $0-1193$ & 6.7 & - \\
\hline Park, 1983 & Antarctic waters & $0-1230$ & $7.83-9.16$ & $6.50-6.75$ \\
\hline Present record & Izu region & $0-1000$ & $7.95-8.80$ & $6.60-6.95$ \\
\hline
\end{tabular}

\section{Phaenna Claus, 1863}

Phaenna spinifera Glaus, 1863

Phaenna spinifera Claus, 1863, p. 189, pl. 31, figs. 1-7; Giesbrecht, 1892, p. 293, pl. 5, fig. 3, pl. 12, figs. 1-18, 35-37, pl. 37, figs. 17-21; T. Scott, 1894, p. 81, pl. 6, fig. 35, pl. 7, figs. 1, 2; A. Scott, 1909, p. 80; With, 1915, p. 241, fig. 79, pl. 7, fig. 1; Mori, 1937, p. 54, pl. 27, figs. 9-15; Vervoort, 1950b, p. 93, figs. 1-6; Tanaka, 1960, p. 85, fig. 81 ; Grice, 1962, p. 203, pl. 15, fig. 1; Chen and Zhang, 1965, p. 57, pl. 17, figs. 9-12; Vervoort, 1965, p. 25; Bradford et al., 1983, p. 70, figs. 34, 35, 89; Park, 1983, figs. 1, 2.

Onchocalanus nudipes Wilson, 1942, p. 179, figs. 71-83.

Occurrence: Sta. 93-1, 1; Sta. 96, 1; Sta. 97-2, 1; Sta. 108, 19; Sta. 1172, 1 우 Sta. 122, 2 ㅇ․

Distribution and size variation:

The species is widely distributed in the Atlantic and Indo-Pacific Oceans (Vervoort, 1965). Body length of the present female specimens varied from 1.60 to 2.73 $\mathrm{mm}$.

\section{Xanthocalanus Giesbrecht, 1892}

Xanthocalanus greeni Farran, 1905

Xanthocalanus greeni Farran, 1905, p. 39, pl. 8, figs. 1-13; With, 1915, p. 235, pl. 7, fig. 3, pl. 8, fig. 18; Sars, 1925, p. 132, pl. 36; Sewell, 1947, p. 132. fig. 31; Vervoort, 1965, p. 27; Tanaka and Omori, 1967, p. 247; Park, 1983, p. 325, figs. 5, 6.

Xanthocalanus calaminus Wolfenden, 1906, p. 34, pl. 11, figs. 3-5.

Talacalanus calaminus Wolfenden, 1911, p. 279, fig. 44, pl. 31, figs. 9-12; Campaner, 1978, p. 976.

Occurrence: Sta. 77,1 ㅇ․

Remarks: This species has previously been reported by us (Tanaka and Omori, 1967). Campaner (1978) redefined and separated Talacalanus Wolfenden from Xanthocalanus, recognizing that Talacalanus differs from Xanthocalanus mainly by the shape of the female's broad razor-like setae (fleshy setae in the male) on first inner lobe of maxillule and by the setation of endopodal segments of maxilliped. According to him, Xanthocalanus greeni, with which $X$. calaminus is considered synonimous 
(With, 1915), X: maximus Brodsky and Grice's (1973) Xanthocalanus sp. 2 also belong to this genus. However, Park (1983) claims removal of the three species to a separate genus is not justifiable, as all basic morphological features of these species agree with the type species of Xanthocalanus. We support this opinion.

\section{Distribution and size variation:}

Author
Farran, 1905, 1908
Wolfenden, 1911
With, 1915
Sars, 1925
Sewell, 1947
Tanaka and
Omori, 1967
Campaner, 1978
Park, 1983

\begin{tabular}{llll} 
Locality & Depth $(\mathrm{m})$ & \multicolumn{2}{c}{ Body length $(\mathrm{mm})$} \\
& & $q$ & $0^{\star}$ \\
Irish Atlantic slope & $1244-2105$ & $6.00-10.0$ & - \\
Bay of Biscay & - & 5.50 & - \\
Off Iceland & - & - & 8.12 (juv.) \\
North Atlantic & $0-1500$ & 8.0 & 6.50 \\
Arabian Sea & $0-850$ & - & 7.1 \\
Izu region & $0-1800$ & 8.6 & - \\
& & & - \\
Off southern Brazil & - & 9.5 & - \\
Antarctic and & $0-1275$ & $8.91-10.50$ & -
\end{tabular}

Xanthocalanus maximus Brodsky, 1950

(Fig. $8 \mathrm{~g}, \mathrm{~h}$ )

Xanthocalanus maximus Brodsky, 1950, p. 227, fig. 139; Tanaka and Omori, 1967, p. 247, figs. 3, 4.

Occurrence: Sta. 111-2, 1 ㅇ․

Remarks: Re-examination of female specimen described by Tanaka and $\mathrm{O}$ mori (1967) revealed that the leaf-like seta on fifth lobe of maxilla is not as long as illustrated in their report and that endopod of the same appendage armed with 1 long vermiform and 7 short brushform sensory filaments, instead of 8 bud-like filaments.

\section{Xanthocalanus pinguis Farran, 1905}

Xanthocalanus pinguis Farran, 1905, p. 39, pl. 8, figs. 18-24, pl. 9, figs. 1-6; 1908, p. 48, pl. 4, fig. 18;

With, 1915, p. 236, pl. 7, fig. 2, textfig. 77; Sars, 1925. p. 130, pl. 35, figs. 8-10; Wilson, 1932 , p. 71, fig. 48; Tanaka, 1960, p. 87, fig. 82; Grice and Hulsemann, 1968, p. 332, figs. 60-62.

Xanthocalanus profundus Sars?. -Tanaka, 1960, p. 89, fig. 83.

Occurrence: Sta. 93-2, 2 9.

Remarks: Re-examination of the female specimen described by Tanaka (1960) under the name $X$. profundus? revealed that it is identical to $X$. pinguis. Two females of $X$. pinguis reported by Grice and Hulsemann (1968) are extraordinarily larger than the previously known specimens. Their second segment of fifth legs appears to be slender than that of type specimen.

Distribution and size variation: 


\begin{tabular}{lllll} 
Author & Locality & Depth $(\mathrm{m})$ & \multicolumn{2}{c}{ Body length (mm) } \\
& & & + & $\delta$ \\
Farran, 1905, 1908 & Irish Atlantic slope & $0-1153$ & $4.5,5.1$ & - \\
With, 1915 & Off Iceland & $0-1700$ & 5.19 & - \\
Sars, 1925 & Off Canarys & $0-5258$ & 7.3 & - \\
Wilson, 1932 & Off Long Island & - & $4.5-5.25$ & 5.0 (juv.) \\
Tanaka, 1960 & Izu region & $0-1000$ & $4.69,5.41$ & - \\
$\begin{array}{l}\text { Grice and Hulse- } \\
\text { mann, 1968 }\end{array}$ & Southeastern Pacific & $0-3790$ & $8.00,8.91$ & - \\
Present record & Izu region & $0-1300$ & $4.80,5.06$ & -
\end{tabular}

Xanthocalanus serratus (Tanaka, 1960)

Amallophora serrata Tanaka, 1960, p. 104, fig. 90.

Occurrence: Sta. 93-2, 1 \%.

Remarks: The present specimen agreed with previous description of Tanaka (1960). This species resembles to $X$. greeni, but is distinguishable from the latter by relatively small size, and by shape of fifth left leg which lacks large spine-like endopod and pyriform distal segment of exopod.

The genus Amallophora was first described by T. Scott (1894) from one male specimen, but later it was considered junior synonym of Xanthocalanus by Giesbrecht (Giesbrecht and Schmeil, 1898). Reason of the confusion concerning Amallophora and Xanthocalanus is explained by Bradford (1973), and now there is no reason for keeping the two genera separately. Accordingly, we suggest that Amallophora crassirostris, A. cornifer, A. irritans, A. oculata and A. serrata from the Izu region (Tanaka, $1960)$ should be transferred to Xanthocalanus. Females of these species are unknown, but most probably, some could be the males of known species of which only the females are known.

Distribution and size variation:

$\begin{array}{llll}\text { Author } & \text { Locality } & \text { Depth }(\mathrm{m}) & \text { Body length }(\mathrm{mm}) \\ & & & 0 \\ \text { Tanaka } & \text { Izu region } & 0-1000 & 5.19 \\ \text { Present record } & \text { Izu region } & 0-1300 & 5.25\end{array}$

\section{Acknowledgements}

The authors are indebted to the late Dr. T. Itô for his critical reading of the manuscript.

\section{References}

This is an additional list of references, supplementing those published in Tanaka and Omori: Additional Report on Calanoid Copepods from the Izu Region, Parts 1 to 5.

Andronov, V.N. 1981. [Xantharus formosus gen. et sp. n. (Copepoda, Calanoida) from the northwest Atlantic.] Zoologicheskii Zhurnal, 9: 1719-1722. (In Russian).

Bradford, J.M. 1973. Revision of family and some generic definitions in the Phaennidae and Scolecithricidae (Copepoda: Calanoida). N.Z. Jour. mar. freshw. Res., 7: 133-152. 
L. Haakonssen and J.B. Jillett, 1983. The marine fauna of New Zealand: Pelagic calanoid copepods: Families Euchaetidae, Phaennidae, Scolecithricidae, Diaixidae, and Tharybidae. N.Z. Oceanogr. Inst. Memoir, 90: 1-150.

Brodsky, K.A. and J.A. Zvereva. 1976. New species of Cornucalanus from the Bering Sea and the Antarctic and the description of Cornucalanus indicus Sewell male (Copepoda, Calanoida). Grustaceana, 31 : 181-189.

Campaner, A.F. 1978. On some new planktobenthic Aetideidae and Phaennidae (Copepoda, Calanoida) from the Brazilian continental shelf. II. Phaennidac. Ciênca e Cultura, 30: 966-982.

Chen, Q-c. and S-z. Zhang. 1965. The planktonic copepods of the Yellow Sea and the East China Sea. I. Calanoida. Studia Marina Sinica, 7: 20-131, pls 1-53. (In Chinese).

Grice, G.D. 1969. Calanoid copepods from the Caribbean Sea and Gulf of Mexico. 1. New species and new records from midwater trawl samples. Bull. mar. Sci., 19:446-455.

1973. The existence of a bottom-living calanoid copepod fauna in deep water with description of five new species. Crustaceana, $23: 219-242$, pl. 1.

Marques, E. 1956. Copépodes marinhos de Angola. Trabalhos de Missão de Biologia maritima. Campanhas em Angola. Ann. Janta Invest. Ultramar, 8 (2): 1-30.

Park, T. 1983. Calanoid copepods of the family Phaennidae from Antarctic and subantarctic waters. Biology of the Antarctic Seas 14, Antarctic Res. Ser., 39: 317-368.

Steuer, A. 1926. Copepoda: Cephalophanes G.O. Sars 1907 der Deutschen Tiefsee-Expedition. Systematik und Verbreitung der Gattung. Wiss. Ergebn. Deutschen Tiefsee-Exped. Dampfer "Valdivia" 1898-1899, 23: 179-191.

Tanaka, O. 1960. The pelagic copepods of the Izu region, middle Japan. Systematic account VI. Families Phaennidae and Tharybidae. Publ. Seto mar. biol. Lab., 8: 85-135.

Thompson, I.C. 1903. Report on the Copepoda obtained by Mr. George Murray, F.R.S., during the cruise of the "Oceana" in 1898. Ann. Mag. nat. Hist., 7 (12): 1-36, pls. 1-7.

Vervoort, W. 1950a. The genus Onchocalanus G.O. Sars, 1905 (Crustacea Copepoda). Zool. Verh. Leiden, (10), 1-35.

- 1950b. On the identity of Onchocalanus nudipes C.B. Wilson, 1942. Proc. Acad. Sci. Amst., 53: $83-92$.

Wilson, C.B. 1942. The copepods of the plankton gathered during the last cruise of the Carnegie. Carnegie Inst. Wash. Publ., (536): 1-237. 